\title{
PENGARUH LATIHAN BEBAN TERHADAP KADAR TRIGLISERIDA LANSIA DI PANTI WREDHA BETANIA LEMBEAN
}

\author{
${ }^{1}$ Mirani A. Uga \\ Damajanty H. C. Pangemanan \\ Sylvia Marunduh \\ ${ }^{2}$ Bagian Fisiologi Fakultas Kedokteran Sam Ratulangi \\ Email: m.uga11_030@yahoo.co.id
}

${ }^{1}$ Kandidat Skripsi Fakultas Kedokteran Universitas Sam Ratulangi

\begin{abstract}
Triglyceride is the main fat in the body, was formed in the liver from glycerol and fat from food or from excess calories due to overeating. Elderly individuals who are aging resulting in a progressive loss of muscle mass and replaced by fatty tissue. Increased levels of fat (triglycerides) elderly is also caused by a decrease in the ability of their activities as usual. This study aims to prove whether or not the effect of weight training on elderly triglyceride levels. This study is an experimental field with research design one group pre-post test and the sample size of 30 elderly. This research was conducted at Panti Wredha Lembean Bethany began in November 2014 until January 2015. Weight training on the left and right upper extremity was performed twice a week in a period of one month. This study showed a decrease in triglyceride levels in the elderly after a given intervention of weight training for a month. The analysis results obtained by the $\alpha=0.00(<0.05)$, which means there is a significant difference between weight training and triglyceride levels elderly.
\end{abstract}

Keywords: triglycerides, weight training, elderly

\begin{abstract}
Abstrak : Trigliserida merupakan lemak utama di dalam tubuh, dibentuk di hati dari gliserol dan lemak yang berasal dari makanan atau dari kelebihan kalori akibat makan berlebihan. Lansia adalah individu yang mengalami proses penuaan yang mengakibatkan terjadinya kehilangan massa otot secara progressif dan terganti dengan jaringan lemak. Peningkatan kadar lemak (trigliserida) lansia juga disebabkan oleh penurunan kemampuan beraktifitas sebagaimana biasanya. Penelitian ini bertujuan untuk membuktikan ada atau tidaknya pengaruh latihan beban terhadap kadar trigliserida lansia. Penelitian ini bersifat eksperimental lapangan dengan menggunakan desain penelitian one group pre-post test dan jumlah sampel 30 orang lansia. Penelitian ini dilaksanakan di Panti Wredha Betania Lembean dimulai pada bulan November 2014 sampai Januari 2015. Latihan beban pada ekstremitas atas kiri dan kanan dilakukan dua kali seminggu dalam jangka waktu satu bulan. Penelitian ini menunjukkan terjadinya penurunan kadar trigliserida pada lansia setelah diberi intervensi latihan beban selama satu bulan. Analisis Hasil yang diperoleh yaitu $\alpha=0.00(<0.05)$ yang berarti terdapat pengaruh yang signifikan antara latihan beban dan kadar trigliserida lansia.
\end{abstract}

Kata Kunci: trigliserida, latihan beban, lansia

Lanjut usia menurut Undang-undang Nomor 13 tahun 1998 tentang Kesejahteraan Lanjut Usia adalah penduduk yang telah mencapai usia 60 tahun ke atas. Pertumbuhan penduduk lanjut usia (lansia) meningkat secara cepat pada abad 21 ini. Pada tahun 2000 jumlah lansia di dunia telah mencapai 425 juta jiwa ( $\pm 6,8$ persen). Indonesia merupakan negara urutan ke-4 dengan jumlah lansia 
paling banyak sesudah Cina, India dan Amerika Serikat dimana terdapat 15.262.199 atau 7,28\% dari total populasi. Jumlah ini diperkirakan akan mengalami peningkatan hampir dua kali lipat pada tahun 2025. ${ }^{1}$

Umumnya ketika seseorang memasuki usia lanjut, mereka sering mempunyai gambaran yang serba buruk atas proses penuaan misalnya kondisi kesehatan yang memburuk, sering sakit sakitan, tidak berdaya, pikun dan sebagainya. Banyak orang beranggapan bahwa hal itu disebabkan oleh penyakit yang muncul pada manusia. Lanjut usia adalah hal yang biasa. Anggapan ini tidak sepenuhnya benar karena kelompok lanjut usia juga bisa dan punya kesempatan dan hak untuk tetap hidup sehat. Sebagian besar penyebab kesehatan yang mengganggu lansia adalah terjadinya proses degenerasi sistem faaliah yang cukup drastis akibat tidak adanya upaya meminimalisasi proses penuaan dan degenerative melalui berbagai aktifitas fisik dan kontrol kesehatan yang rutin. ${ }^{2}$ Penuaan pada manusia ditandai dengan kehilangan lean body mass yang biasanya sudah dimulai sejak usia 40 tahun disertai dengan menurunnya metabolisme basal sebesar $2 \%$ yang kemudian disertai dengan perubahan pada semua sistem dalam tubuh manusia. Lean body massa dan metabolisme dalam sel-sel otot mengalami pengurangan seiring dengan pertambahan usia. Adanya penurunan kekuatan otot sering mengakibatkan orang merasa letih dan merasa lemah serta daya tahan tubuh menurun. Protein juga mengalami penurunan. Adanya pengurangan protein pada tubuh akan menambah lemak. Perubahan metabolisme lemak ditandai dengan naiknya kadar kolesterol total dan trigliserida. $^{3}$

Sebagian besar lemak dalam makanan berada dalam bentuk trigliserida, yaitu lemak netral yang terdiri dari satu molekul gliserol dan tigal asam lemak melekat padanya. Selama pencernaan dua atau tiga molekul asam lemak itu terpisah meninggalkan satu molekul monogliserida, satu molekul gliserol dengan satu molekul asam lemak. Karena itu produk akhir pencernaan lemak adalah monogliserida dan asam lemak bebas yang dapat diserap. ${ }^{4}$

Tahap pertama proses penggunaan trigliserida unutk energi adalah hidrolisis trigliserida menjadi asam lemak dan gliserol. Setelah itu, asam lemak dan gliserol ditranspor dalam darah ke jaringan yang aktif tempat oksidasi kedua zat untuk menghasilkan energi. Hampir semua sel (dengan pengecualian jaringan otak dan sel darah merah) dapat menggunakan asam lemak sebagai sumber energi. Gliserol sewaktu memasuki jaringan yang aktif, segera diubah menjadi gliserol 3-fosfat oleh enzim intrasel yang memasuki jalur glikolisis untuk pemecahan glukosa dan kemudian dipakai untuk menghasilkan energi. ${ }^{5}$

Aktivitas fisik pada lansia sebaiknya memenuhi kriteria FITT (frequency, intensity, time, type). Frekuensi adalah seberapa sering aktivitas dilakukan, berapa hari dalam satu minggu. Intensitas adalah seberapa keras suatu aktivitas dilakukan. Biasanya diklasifikasikan menjadi intensitas rendah, sedang dan tinggi. Waktu mengacu pada durasi, yaitu seberapa lama suatu aktivitas dilakukan dalam satu pertemuan, sedangkan jenis aktivitas adalah jenis-jenis latihan apa saja yang bisa diberikan pada lansia.

Bagi lansia disarankan untuk menambah latihan penguatan otot disamping latihan aerobik. Kebugaran otot memungkinkan melakukan kegiatan seharihari secara mandiri.

Latihan fisik untuk penguatan otot adalah aktivitas yang memperkuat diri menyokong otot dan jaringan ikat. Latihan dirancang supaya otot mampu membentuk kekuatan untuk menggerakkan atau menahan beban, misalnya aktivitas yang melawan gravitasi seperti gerakan berdiri dari kursi, ditahan beberapa detik, berulang-ulang atau aktivitas dengan tahanan tertentu misalnya latihan dengan angkat beban. ). Latihan penguatan otot dilakukan setidaknya 2 hari dalam seminggu dengan istrahat di antara sesi untuk masing-masing kelompok otot. 
Intensitas untuk membentuk kekuatan otot menggunakan tahanan atau beban dengan 10-12 repetisi untuk masimg-masing latihan.Intensitas latihan meningkat seiring dengan meningkatnya kemampuan individu. Jumlah repetisi harus ditingkatkan sebelum beban ditambah. Dalam satu sesi latihan dibutuhkan 10-15 kali reprtisi. Bagi lansia yang lemah secara fisik, aktivitas yang dilakukan dikaitkan dengan kegiatan sehari-hari dan mempertahankan kemandirian, misalnya teknik mengangkat beban yang benar, berjalan, cara menjaga postur yang benar, dan sebagainya. ${ }^{6}$

\section{METODE PENELITIAN}

Penelitian ini menggunakan desain penelitian eksperimental lapangan dengan rancangan pre - post one group test. Subyek penelitian berjumlah 30 orang lansia di Panti Wredha Betania Lembean yang diambil dengan metode random sampling sesuai dengan kriteria seperti: berusia $\geq 60$ tahun, lansia yang sehat dan aktif, lansia yang bersedia berpartisipasi pada penelitian, dan lansia yang mengisi informed consent. Penelitian ini dilakukan dari bulan November 2014 -Desember 2015. Pada subjek dilakukan pengambilan darah sebelum dan setelah latihan beban pada ekstremitas atas untuk melihat ada tidaknya perubahan kadar trigliserida darah. Hasil kadar trigliserida yang diperoleh diuji menggunakan uji Wilcoxon untuk melihat ada tidaknya pengaruh latihan beban terhadap kadar trigliserida lansia dengan menggunakan $\alpha=0,05$.

\section{HASIL PENELITIAN}

Dari tabel 1 dapat dilihat bahwa dari 30 orang yang menjadi sampel penelitian , 20 orang(66,7\%) diantaranya adalah perempuan dan sisanya 10 orang(33,3\%) adalah laki-laki. Sehingga dapat dikatakan bahwa pada penelitian ini lansia perempuan lebih dominan dibanding lansia laki-laki.

Untuk data hasil berdasarkan usia dapat dilihat pada tabel. 2. Berdasarkan data dari tabel 2 diperoleh jumlah lansia dengan rentang usia 60-69 tahun berjumlah
8 orang (26,7\%), berbeda dengan lansia dengan rentang usia 70-79 tahun berjumlah 12 (40\%), untuk lansia dengan rentang usia 80-89 tahun berjumlah 7 orang (23,3\%). Sedangkan lansia yang berada pada rentang usia 90-99 berjumlah 3 orang (10\%). Sehingga dapat disimpulkan bahwa sampel terbanyak pada penelitian ini berada pada rentang usia 70-79 (40 \%).

Tabel 1. Klasifikasi berdasarkan jenis kelamin

\begin{tabular}{lcc}
\hline Jenis Kelamin & $\mathrm{n}$ & $\%$ \\
\hline Laki-laki & 10 & 33,3 \\
Perempuan & 20 & 66,7 \\
Total & 30 & 100 \\
\hline
\end{tabular}

Tabel 2. Klasifikasi berdasarkan usia

\begin{tabular}{lcl}
\hline Umur (tahun ) & $\mathrm{n}$ & $\%$ \\
\hline $60-69$ & 8 & 26,7 \\
$70-79$ & 12 & 40 \\
$80-89$ & 7 & 23,3 \\
$90-99$ & 3 & 10 \\
Total & 30 & 100
\end{tabular}

Dari diagram di bawah dapat dilihat untuk pengukuran trigliserida pre-test, bahwa jumlah lansia dengan kadar trigliserida normal adalah 24 orang (80.0\%), sedangkan untuk lansia dengan kadar trigliserida yang termasuk kategori borderline high berjumlah 4 orang (13.3\%). Lansia yang termasuk dalam kategori kadar trigliserida tinggi berjumlah 2 orang (6.7\%).

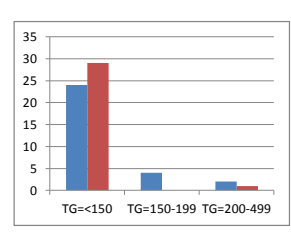

Gambar 1. Perbandingan trigliserida pre dan post test

Biru: Trigliserida Pre, Merah: Trigliserida Post 
Pada pengambilan darah post-test dapat dilihat bahwa lansia yang termasuk dalam kategori trigliserida normal berjumlah 29 orang (96.7\%), dan lansia kategori trigliserida tinggi berjumlah 1 orang (3.3\%).

Dapat dilihat pula terjadi penurunan hasil pengukuran kadar trigliserida pre-test dan post-test pada lansia yang diberikan intervensi berupa latihan beban pada ekstremitas atas kanan dan kiri, walaupun ada beberapa lansia yang mengalami peningkatan kadar trigliserida. Hal ini terjadi karena banyak faktor salah satunya sampel tidak mengikuti kegiatan latihan beban dengan baik, tidak puasa sebelum proses pengambilan darah dan sebagainya.

Pada gambar 2 diperoleh hasil rata-rata trigliserida sebelum diberikan intervensi latihan beban pada ekstremitas atas kiri dan kanan lansia yaitu $109.93 \mathrm{mg} / \mathrm{dL}$, sedangkan untuk hasil pemeriksaan trigliserida setelah intervensi yaitu 75.06 $\mathrm{mg} / \mathrm{dL}$. Uji Wilcoxon digunakan untuk mengetahui pengaruh latihan beban terhadap kadar trigliserida lansia, diperoleh hasil $\alpha=0.00(<0.05)$ yang berarti terdapat perbedaan yang signifikan pada hasil pengukuran trigliserida sebelum dan setelah diberikan intervensi.

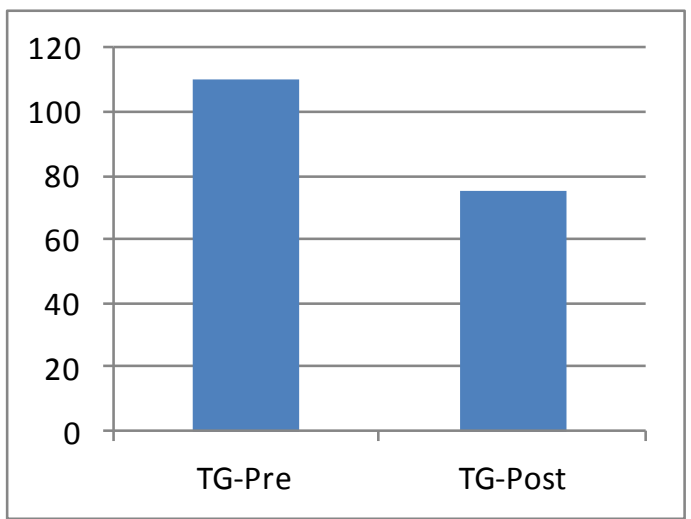

Gambar 2. Pebandingan rata-rata trigliserida pre dan post test.

TG-pre=109.93

TG-post $=75.06$

\section{BAHASAN}

Pada penelitian ini peneliti menitik beratkan pada trigliserida sebagai variabel yang akan diteliti dimana kadar trigliserida diukur setelah diberikan latihan beban pada lansia selama satu bulan dengan interval waktu dua kali dalam satu minggu.

Analisis hasil penelitian ini menggunakan uji Wilcoxon untuk membandingkan perbedaan kadar trigliserida lansia sebelum dan setelah dilakukan latihan beban selama 1 bulan, dan didapatkan $\alpha=0.00$ yang berarti terdapat pengaruh signifikan antara latihan beban dan kadar trigliserida lansia.

Berdasarkan hasil penelitian yang didapatkan dapat dilihat bahwa penurunan kadar trigliserida sendiri dapat terjadi karena beberapa faktor diantaranya:

a. Peningkatan aktivitas lansia.

b. Peningkatan kerja jantung akibat latihan behban yang dilakukan.

c. Terjadi peningkatan proses lipolisis untuk mengkompensasi pemakaian energi yang berlebih.

Trigliserida seperti yang telah dijelaskan sebelumnya mempunyai berbagai fungsi dalam tubuh manusia salah satunya sebagai sumber energi. Fungsi lipid ini mempunyai peranan yang hampir sama dengan karbohidrat yaitu memberi energi untuk tubuh. Fungsi lain yang tidak kalah penting dari trigliserida bagi tubuh manusia adalah sebagai energi cadangan yang dapat digunakan tubuh saat membutuhkan energi segera. $^{4}$

Kelebihan makanan berlemak yang dikonsumsi tubuh, akan disimpan sebagai lemak tubuh untuk digunakan jika kalori berkurang dalam jangka waktu lama. Kapasitas lemak kalori berguna jika kalori glukosa telah habis terpakai. Lemak tersimpan di dalam jaringan lemak yang disebut adiposit, sedangkan bentuk jaringan lemak tubuh dimanakan adipose. Sel tubuh akan melepaskan trigliserida dan asam lemak dan mengirim melalui aliran darah ke sel yang membutuhkan energi. ${ }^{5}$

Kondisi penurunan trigliserida plasma dapat dipicu oleh olahraga akut dalam jangka waktu pendek. Penelitian sebelumnya didapatkan bahwa kondisi penurunan trigliserida plasma ini terjadi 
dalam 12 hingga 18 jam pasca olahraga dan bertahan 2-3 hari. Penurunan trigliserida tersebut disebabkan oleh turunnya konsentrasi trigliserida dalam bentuk VLDL serta karena dibutuhkannya sejumlah energi selama olah raga. Latihan jangka panjang tidak dapat mempertahankan penurunan trigliserida dalam plasma secara menetap, olahraga harus dilakukan secara teratur setidaknya setiap 3 hari agar kadar trigliserida tetap terjaga.

Pada penelitian sebelumnya tentang perubahan kadar trigiserida pada latihan beban mahasiswi oleh Munawwar M pada tahun 2011, dimana sampel dibagi dalam dua kelompok yaitu kelompok yang mendapat perlakuan latihan interval dan kelompok dengan pelatihan interval dan ditambah dengan latihan kekuatan otot. Kelompok latihan interval ditambah latihan kekuatan otot mengalami penurunan trigliserida lebih besar dibandingkan dengan kelompok yang hanya mendapat latihan interval. ${ }^{8}$

Penelitian lain juga dilakukan oleh Dahliana pada tahun 2012 dimana pada penelitiannya didapatkan terjadi perubahan yang bermakna antara sebelum dan setelah latihan aerobik. ${ }^{9}$

\section{SIMPULAN}

Berdasarkan hasil penelitian ini dapat disimpulkan terjadi penurunan kadar trigliserida antara sebelum dan setelah intervensi. Hal ini menjelaskan bahwa terdapat pengaruh latihan beban terhadap kadar trigliserida pada lansia di panti wredha Betania Lembean.

\section{DAFTAR PUSTAKA}

1. Badan Pusat Statistik (BPS). Penduduk Lanjut Usia. 2011 [Manado 2014 september15] Available from: http://www.google.co.id/url?sa=t\&rct= $\mathrm{j} \& \mathrm{q}=\&$ esrc $=\mathrm{s} \&$ source $=$ web $\& \mathrm{~cd}=1 \& \mathrm{ca}$ $\mathrm{d}=$ rja\&uact $=8 \&$ ved $=0 \mathrm{CB} 8 \mathrm{QFjAA} \& u r \mathrm{r}$

=http $\% 3 \mathrm{~A} \% 2 \mathrm{~F} \% 2 \mathrm{Fmenegpp}$. go.id\%2F v2\%2Findex.php\%2Fdatadaninformasi \%2Fkependudukan\%3Fdownload\%3D 9\%253Apenduduk-lanjut usia\&ei=TrsaVIG2I4rJuATCnIDYCA \&usg=AFQjCNHdkQyoibWQeoii0_A 9wXeF-

PKUCw\&bvm=bv.75097201,d.c2E .

2. Junaidi S. Pembinaan Fisik Lansia Melalui Aktivitas Olahraga Jalan Kaki. Media Ilmu Keolahragaan Indonesia. 2011;1:18.

3. Haryadi E. Perubahan Fisiologis Lansia. 2011[Manado 2014 oktober 6] . Available from: https://www.deherba.com/seputarperubahan-fisiologis-pada-lansia.html

4. Sherwood L. Fisiologi Manusia Dari Sel ke Sistem. Edisi ke-6. Jakarta: ECG; 2011. p. 642-3.

5. Guyton A.C, Hall J.E. Buku Ajar Fisiologi Kedokteran. Edisi ke-11. Jakarta: ECG; 2006. p. 884-5.

6. Ambardini RL. Aktivitas Fisik Pada Lanjut Usia.Universitas NegeriYogyakarta. [Manado 2014 September 17] Availablefrom :http://staff.uny.ac.id/sites/default/files/ 132256204/Aktivitas\%20Fisik\%20Lan sia.pdf .

7. Fitantra J.B. Pengaruh Olahraga Terhadap Metabolisme Trigliserida. [Manado 2014 september 18]Available from: http://www.medicinesia.com/kedoktera n-dasar/sel-dan-

biomolekuler/pengaruh-olahragaterhadap-metabolisme-trigliserida/.

8. Munawwarah M. Penambahan Latihan Kekuatan Otot pada Pelatihan Interval Menurunkan Interval Trigliserida Mahasiswi Gemuk Universitas Esa Unggul.2011. Universitas Esa Unggul. Vol 11.

9. Dahliana. Pengaruh Pemberian Angkak Pada Senam Aerobik Terhadap Kadar LDL dan Trigliserida Wanita Anggota PKK Kelurahan Demang Lebar Daun Palembang. 2012. 